See discussions, stats, and author profiles for this publication at: https://www.researchgate.net/publication/241654350

\title{
Freedom from Hate: Solidarity and Non-violent Political Struggle in Poland
}

Article in Journal of Human Values · January 2002

DOI: 10.1177/097168580200800106

1 author:

W. Julian Korab-Karpowicz

Opole University

23 PUBLICATIONS 12 CITATIONS

SEE PROFILE

Some of the authors of this publication are also working on these related projects:

Project Philosophy and Myth View project

Political Philosophy View project 
SOLIDARITY AND NONVIOLENT POLITICAL STRUGGLE IN POLAND

\section{W. J. Korab-Karpowicz}

August 31th marks the anniversary of the end of prolonged strikes in the Gdansk Shipyard which resulted in the forming of the Independent Self-Governing Trade Union "Solidarity" in Poland. The peaceful persistence and ethics of Solidarity still remain a powerful lesson in political non-violence. It was the persistent, nonviolent political struggle of Solidarity in the 1980s that consequently led to the downfall of communism in Central and Eastern Europe in 1989 and to dramatic changes that followed all over the world.

Solidarity (in Polish "Solidarnosc"), a trade union and an independent social movement, was born in August 1980 after mass strikes which swept all over Poland. However, in spite of the wide support it enjoyed in Polish society, it was outlawed in December 1981 and its leaders were imprisoned. If one is suppressed by force, one can answer with force. One has a right to defend oneself. The right to self-preservation has been recognized as a fundamental right of an individual, but also of society. Why did Solidarity not answer force with force? Was it an ethical standpoint that Solidarity used peaceful means only in its defense or a utilitarian or pragmatic strategy? Before I answer these questions, I shall first make some remarks about the nature of the communist political system which existed in Poland the World War II. Thus, I wish to point out the sources of injustice that existed in that country. As a response to this injustice, Solidarity arose.

\section{Social Conflict in Classless Society}

An underlying feature of the political system that existed in the People's Republic of Poland from 1945 to 1989 was the presence of communist ideology. In light of this ideology, and since with exception of some small farms and enterprises, private ownership of the means of production was abolished, Polish society was declared to be a classless society in which there was no place for social conflict. ${ }^{1}$ It was believed that conflicts and contradictions between social classes, such as the owners and the employees, would arise from the fact that the former desired more profit and robbed the latter of the full fruit of their labor. Such

\footnotetext{
${ }^{1}$ See Stanislaw Starski, Class Struggle in Classless Poland (Boston: South End Press, 1982).
} 
conflicts would no longer hold in a classless society, in which there was public ownership of the means of production, and everyone who worked was an employee and an owner at the same time.

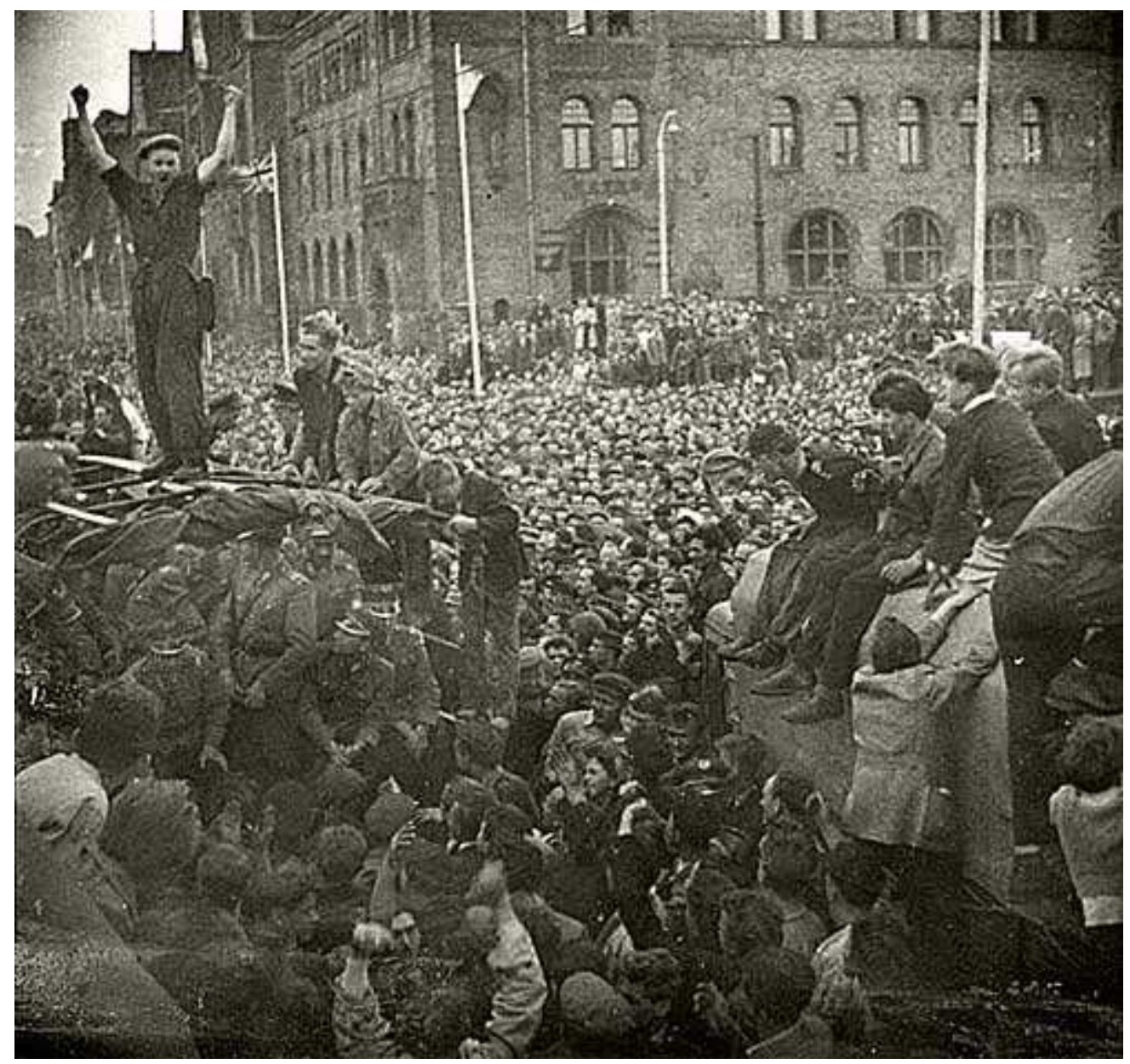

Poznan, workers' protests of 1956.

The results of social conflicts are strikes and demonstrations. There were several cases of strikes and demonstrations in the People's Republic of Poland which seemed to contradict the ideological theory. This is why in Poland, a supposedly classless country, the word "strike" was forbidden. If there was a strike in a factory or an institution, it was called a "work-interruption" by state-controlled mass media. Likewise, any protest march or demonstration was called a "disturbance." Thus, the presence of the theoretical concepts of Marxist-Leninist philosophy, namely, communist ideology, in light of which there should be no conflicts in a classless society, distorted the facts. It made facts nonexistent and made existent things that were fictitious. 


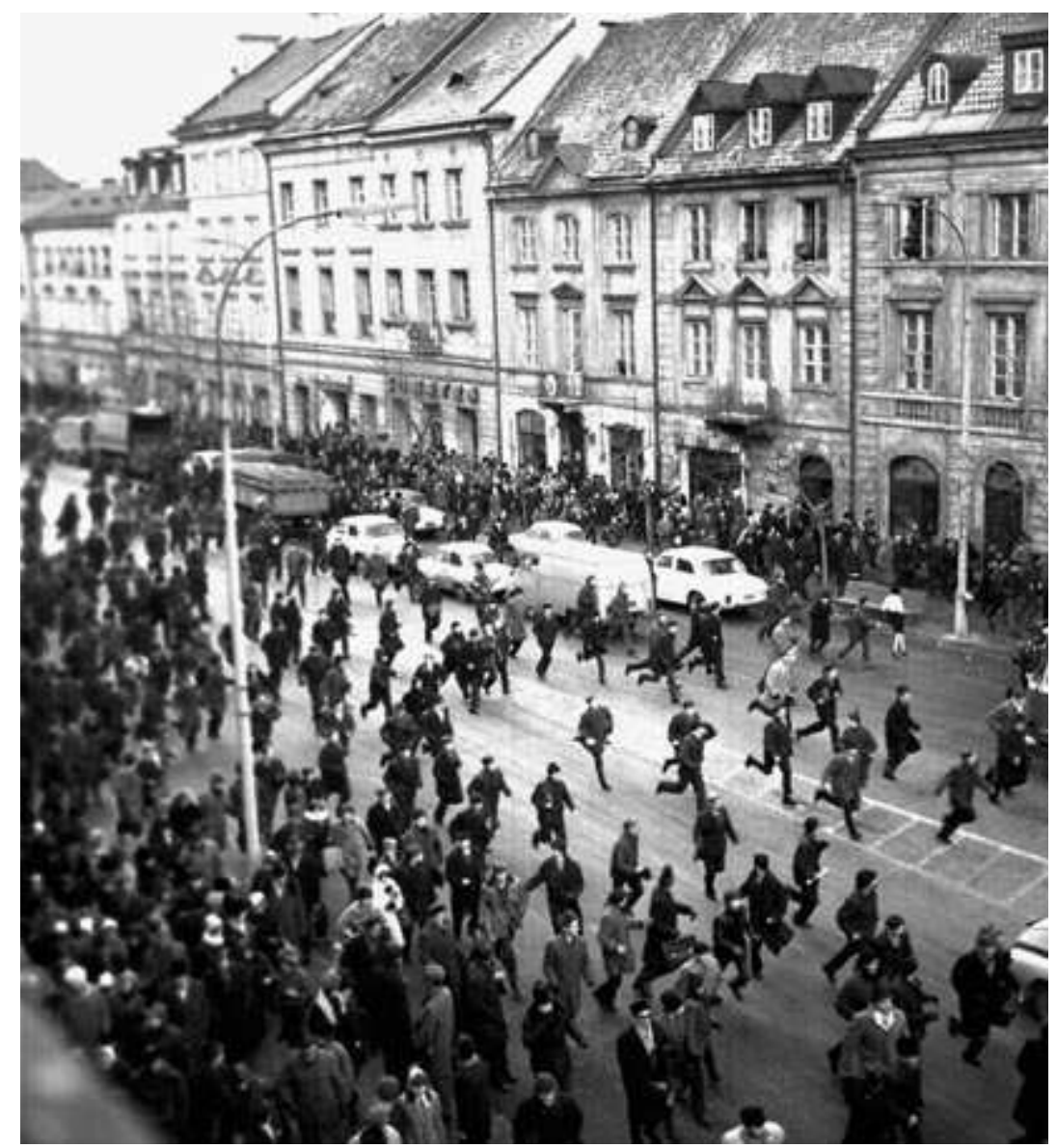

Warsaw, students' protests of 1968.

Perhaps the greatest thing that the ideology concealed was the fact that Polish society of the 1950 's-1980's, a society of so called "real socialism," was a society with inherent social contradictions. The supposedly class society was in truth torn apart by conflicts of interests, not of those who were owners and those who were employees, but of those who held power and those who were controlled. The one-party system and the lack of separation of power, which were characteristic not only of Poland, but of all communist-ruled countries, led to an enormous concentration of power in a few hands. A classless society was thus in fact not classless at all, but characterized by at least two classes, namely, the apparatchiks who held power, and those who were controlled. The popular participation in power, like the elections, were only an illusion. The governments of East European countries which hold power against the will of the majority of their citizens were ironically called "People's Republics" or "People's Democracies". A hierarchical class society built along the rigid lines of the economic, social, and political inequalities between those who control and those who were controlled, was called "classless society." 


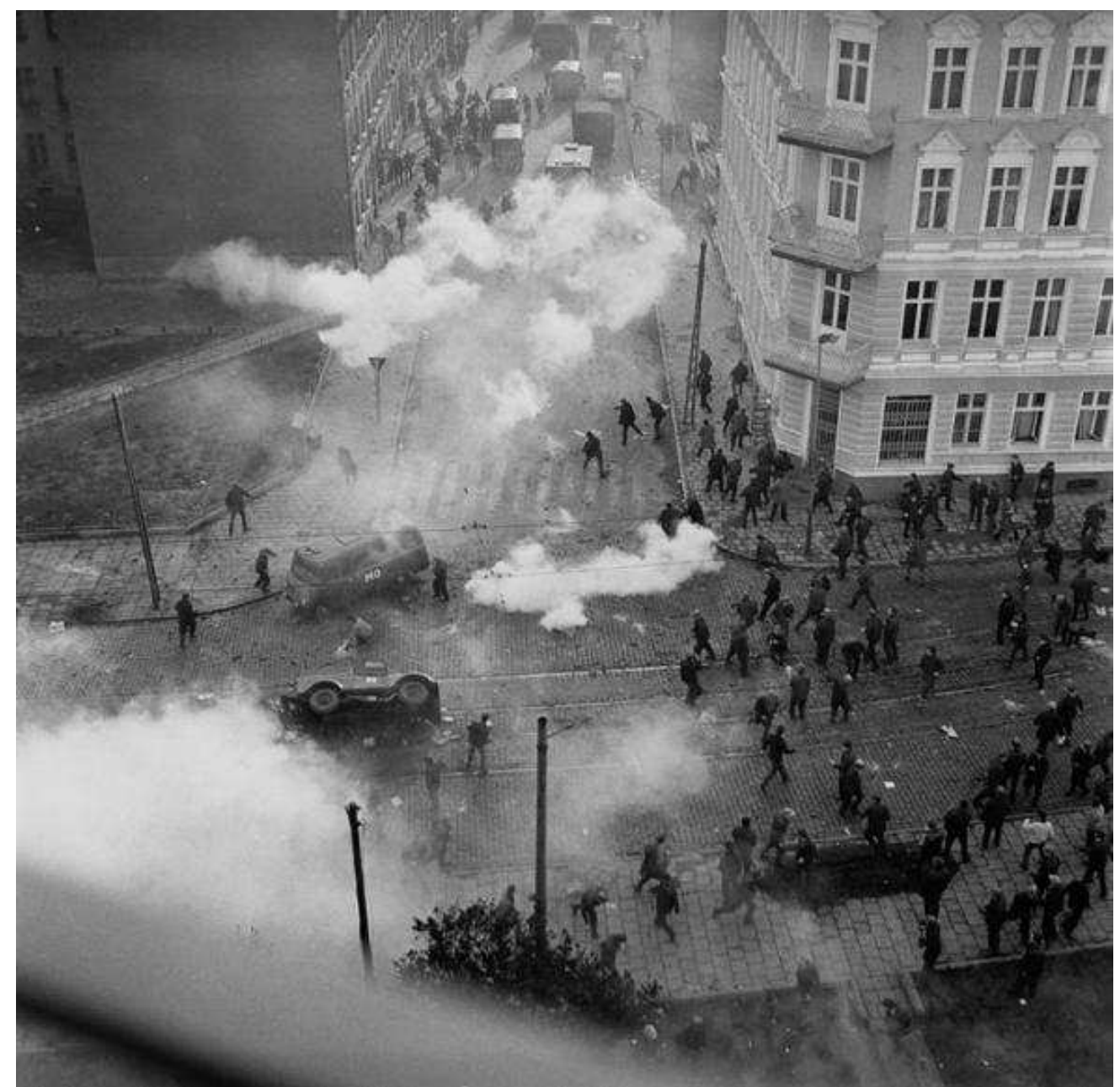

Gdansk and Gdynia, protests of December 1970.

Because of the enormous concentration of power on the one hand and its absence on the other, the communist-ruled countries were endangered by a condition of internal conflict to a degree higher than any of the Western democracies in which there is a separation and checking of power. This explains why the communists developed a vast apparatus of repression, ready to silence any voice that might attempt to challenge their power. Yet, every act of repression was also a step that led oppressed people to realize that that lived in an oppressive kind of regime. Every act of repression aiming at the preservation of an oppressive regime was also, paradoxically, a step leading to its downfall.

Concentration and centralization of power, bureaucratization of its execution, and the manipulation of public opinion, so as to distort the facts, were characteristic of the regime of the People's Republic of Poland. It was also characterized by the oppressive means employed for the sake of its preservation. 


\section{The Burden of Freedom}

It may be astonishing for someone to hear that people do not always desire freedom. They often exchange freedom for security, satisfaction of material goals, or a quiet life. They may thus very well accept regimes that take away from them the responsibility or burden of freedom. In other words, they may let others guide their own lives, and lose almost all powers to participate actively in the decision-making process. In such instances, the best that may be said is that they are governed with consent, but the means of bringing about this consent are often those of suggestion and manipulation. Yet, if there are such people, there are also others, "freedom seekers," those who, in contrast to the former, not only ask whether their life is a good one, but also challenge the life prescribed to them by their administrators. Such people actually take the burden of freedom upon their shoulders. Further, if there is an ideology which assumes that the life prescribed is the best one, then a conflict must inevitably follow between the "freedom seekers" and the authority. In the face of oppression, the former may withdraw from taking responsibility for their own lives, submit to the force of authority and live under suppression. Still, this will not discourage some of them, who will persist in their questioning.

In Poland under the communist regime there was a long list of questions which Polish citizens wanted to ask, but in general were afraid to ask. Some of these questions concerned the criminal way in which the communists seized the political power in Poland. ${ }^{2}$ There were questions about Katyn Forest, ${ }^{3}$ Yalta, and the Home Army, the most powerful Polish underground military organization fighting against the Nazis, whose members were systematically persecuted and often killed by the communists after World War II. However, there were also simple questions concerning basic economic needs. The worker could ask why, in spite of his hard work, he earned so little, and why there was a constant lack of basic products on the market. All workers' protests in Poland would always begin with simple

\footnotetext{
2 See Krystyna Kersten, The Establishment of Communist Rule in Poland, 1943-1948, trans. by John Micgiel and Michael H. Bernhard (Berkeley, California: University of California Press, 1991); Stefan Korbonski, Warsaw in Chains (New York, 1959), Stanislaw Mikolajczyk, The Rape of Poland: The Pattern of Soviet Aggression (Westport, Conn.: Greenwood Press, 1972).

${ }^{3}$ The name Katyn stands for the best known of the three places of the execution by the NKVD, in spring 1940, of 14552 Polish officers, prisoners of war. They were murdered at Katyn, Kalinin/Tver and Kharkov. See Allen Paul, Katyn: The Untold Story of Stalin's Polish massacre (New York, N.Y.: Maxwell Macmillan, 1991); Solomon W. Slowes, The Road to Katyn: A Soldie's Story (Oxford, 1992); Robert Szymczak, "A Matter of Honor: Polonia and the Congressional Investigation of the Katyn Forest Massacre," Polish American Studies, 41 (1) Spring 1984, pp. 25-65; J. K. Zawodny, Death in the Forest: The Story of the Katyn Forest Massacre (Notre Dame, IN: University of Notre Dame Press, 1962); Katyn. Documents of Genocide: Documents and Materials
} 
economic questions and statements of need, and then they would eventually inspire other questions concerning social and political issues, proceeding beyond the mere economic. ${ }^{4}$ Hence, in postwar Poland, the majority of society, even if they wanted to, could not exchange freedom for security or material satisfaction because there was none. With the exception of some periods of greater stabilization, the economic questions have always been acute and the government incapable of solving them, so there was great dissatisfaction with the regime among a the large part of society.

Injustice can be defined as undeserved suffering. People who work hard for small salaries, whose views and questions are silenced, and who if more persistent in their questioning, are persecuted, suffer because of much that they do not deserve. They do not associate their vision of a good life with the life they are actually living. Upon realizing that he is being subjected to injustice, an oppressed person will try to eliminate it. This is how social change may occur. Yet, he must know the sources of injustice. He must understand why is he oppressed and who the oppressor is. This is where the function of political opposition comes about. It is political opposition which prepares the ground for a mass political struggle.

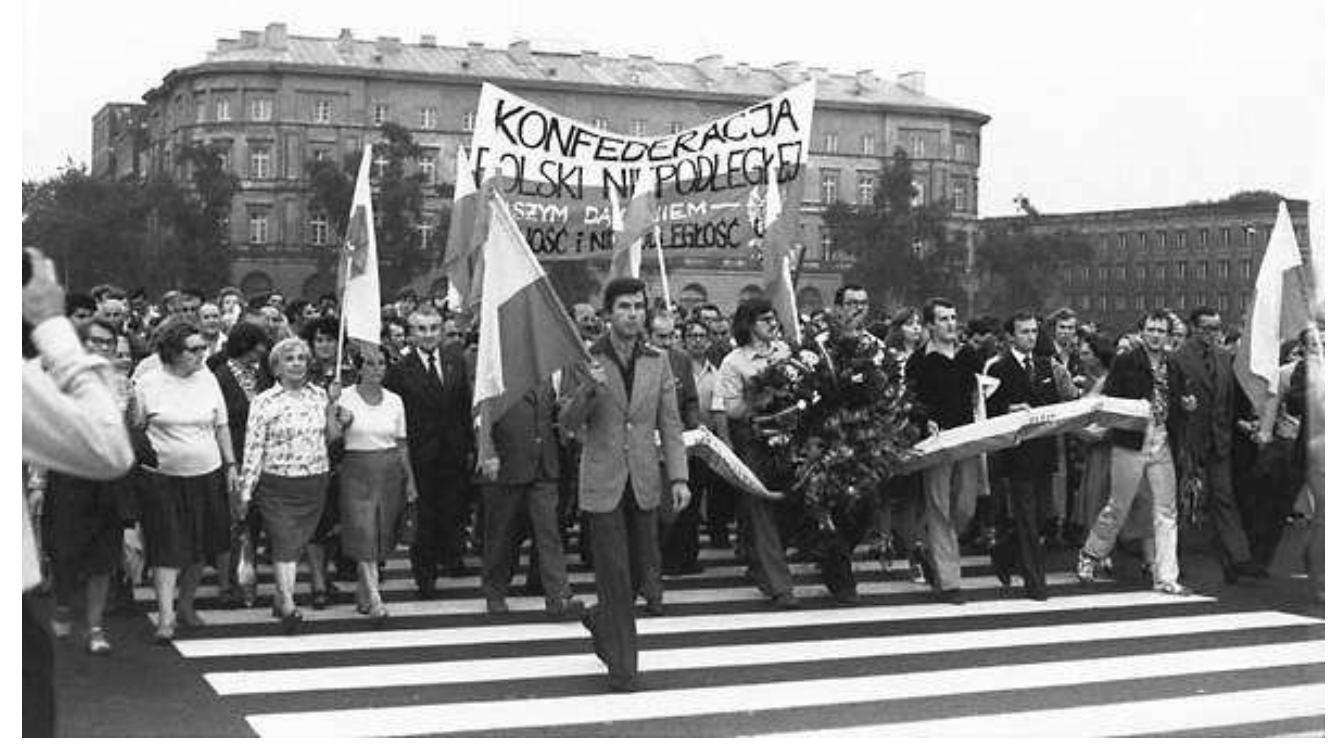

Warsaw, a demonstration of the Confederation of Independent Poland (KPN), 1979.

from the Soviet Archives turned over to Poland on October 14, 1992, trans. and ed. Wojciech Materski, Foreword by J. K. Zawodny (Warsaw: Institute of Political Sciences, 1993).

${ }^{4}$ See Jane Leftwitch Curry and Luba Fajfer, Poland's Permanent Revolutions: Peoples vs. Elites, 1956 to the Present (Washington, D.C.: American University Press, 1996). 
Before 1976, groups of intellectuals had occasionally protested state policies in Poland, but there was no organized opposition movement. ${ }^{5}$ Shocked by the brutal repression of worker's protests against price hikes in June 1976, a small group of intellectuals organized the "Committee for the Defense of the Workers" (Polish acronym KOR). ${ }^{6}$ This first dissident organization was soon joined by others: "The Movement for the Defense of the Rights of Man and Citizen” (ROPCIO), “The Movement of Young Poland” (RMP), and „Confederation of Independent Poland" (KPN). In addition, a large underground press and the "Association for Scholarly Courses" (TKN), an underground educational organization which organized seminars for university students on subjects either not taught at universities or distorted by a Marxist approach, came into being.

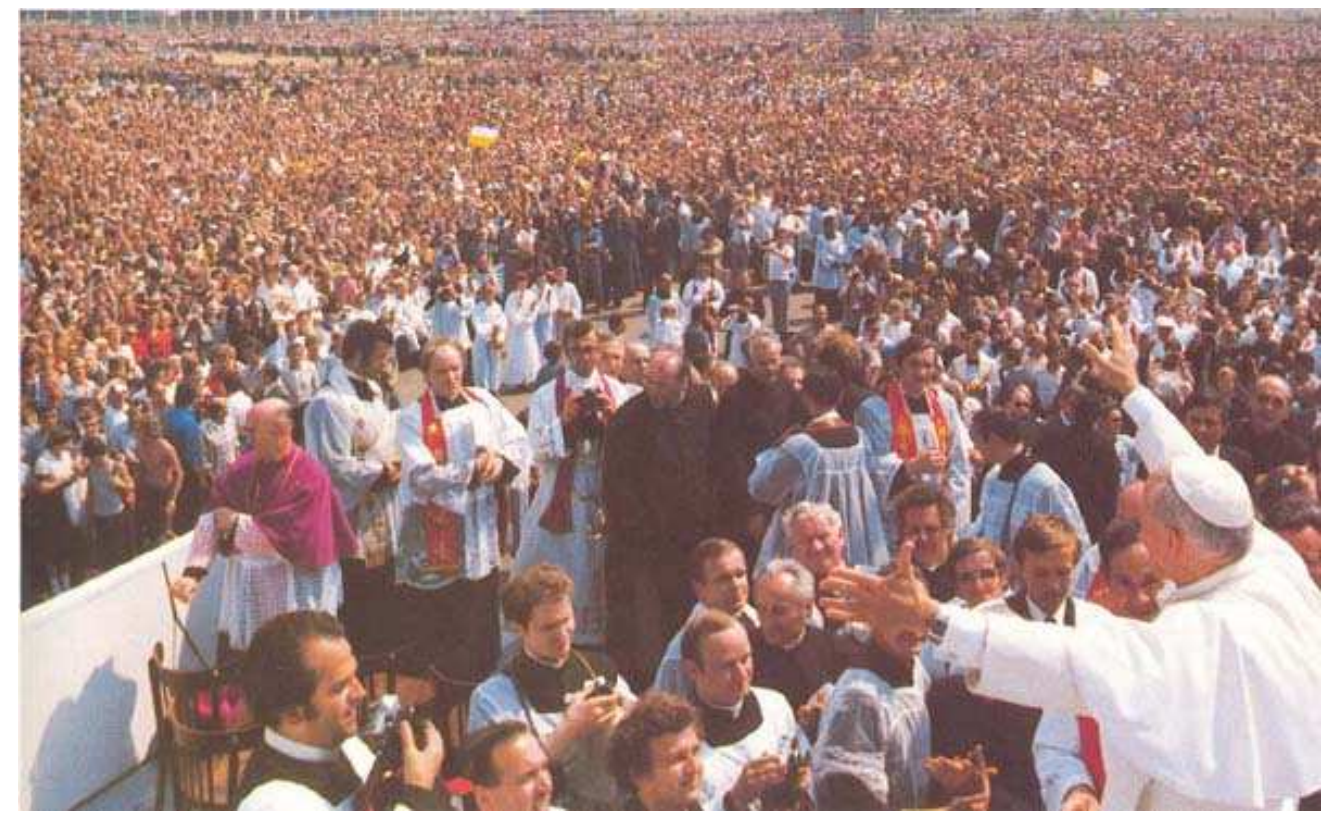

John Paul II during his visit to Poland in 1979.

The Church supported dissident activities. ${ }^{7}$ It was a very joyful day for many people in Poland when on 16 October 1978, Cardinal Karol Wojtyla, Archbishop of Krakow, was elected Pope and took the name of John Paul II. His election strengthened not only the position of the Church in Poland, but also the dissidents. The Pope's first visit to Poland in June 1979 had a tremendous impact on the country. Thousands gathered to attend his open air

\footnotetext{
${ }^{5}$ On the background to August 1980, see Michael H. Bernhard, The Origins of Democratization in Poland.: Workers, Intellectuals and Oppositional Politics, 1976-1980, (New York, N.Y.: Columbia University Press, 1993); Keith John Lepak, Prelude to Solidarity: Poland and the Politics of the Gierek Regime (New York, N.Y.: Columbia University Press, 1988).

6 Jan Jozef Lipski, KOR : a History of the Workers' Defense Committee in Poland, 1976-1981, translated by Olga Amsterdamska and Gene M. Moore (Berkeley, California: University of California Press, 1985).
} 
mass in Warsaw; about one million came to hear him at the Polish national shrine in Jasna Gora; and about two millions heard him in the open fields outside Krakow. John Paul II spoke openly about the right to freedom. Years of communism seemed to vanish overnight as people gathered in millions to listen to and to cheer their Pope. The barrier of fear was broken.

The mass demonstration of Polish Catholicism in June 1979 was a prelude to the birth of Solidarity in August 1980. Four years after the emergence of an organized opposition in Poland and one year after Pope John Paul II's first visit to his home, Polish society was ready to renounce its obedience to the communist regime. The Independent Self-Governing Trade Union „Solidarity” sprang up when people in Poland gained realization of their suffering on such a wide scale that in a few weeks in the summer of 1980, within the country of thirty-five million citizens, an independent union of ten million working people was born. First, the workers' protests of 1956, then the student demonstrations of 1968, then the ruthlessly suppressed workers' protests of 1970 and 1976 - all these events were the precursors of the famous strikes of 1980, when for the first time in the history of Communism, the most revolutionary class according to Marx, namely, the workers, decided to end the very political system that was inspired by his philosophy. ${ }^{8}$ Never before Solidarity were the inherent contradictions of a communist-ruled country seen so clearly.

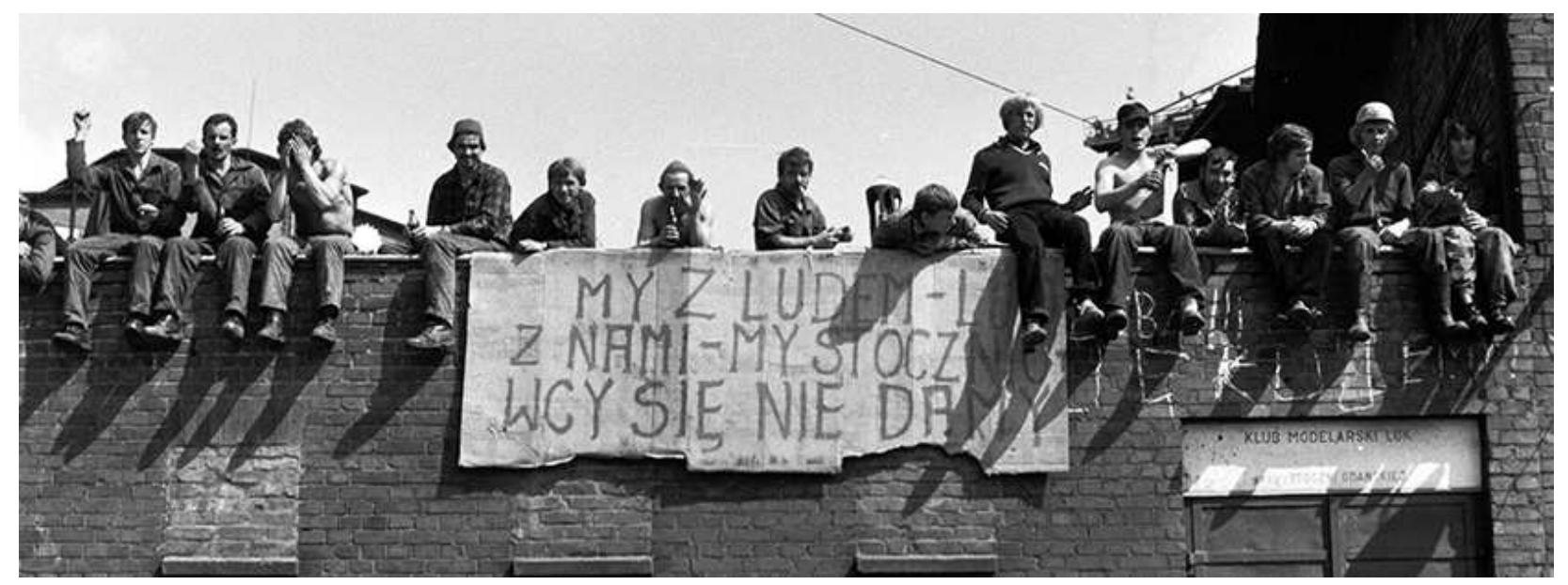

August 1980, the strikers in the Gdansk Shipyard.

\footnotetext{
${ }^{7}$ See Bogdan Szajkowski, Next to God -Poland: Politics and Religion in Contemporary Poland (London : F. Pinter, 1983).

${ }^{8}$ On political developments in Poland, see Curry and Fajfer, Poland's Permanent Revolutions; Jakub Karpinski, Countdown: the Polish Upheavals of 1956,1968,1970, 1976, 1980, translated by Olga Amsterdamska and Gene
} 


\section{The Glorious Birth}

For several days in the summer o 1980 the eyes of the entire world were focused on the Gdansk Shipyard, on the masses of people and their cry for freedom. Foreign observers were shocked by the peaceful nature of the strike. ${ }^{9}$ On August 31, 1980 the government signed an agreement with the worker's representatives (the Strike Committee). The Gdansk agreement known as „21 Points” marked the birth of Solidarity, a free trade union and a social movement independent of the communist power. ${ }^{10}$ There were at least four distinct phenomena connected with the birth of Solidarity.

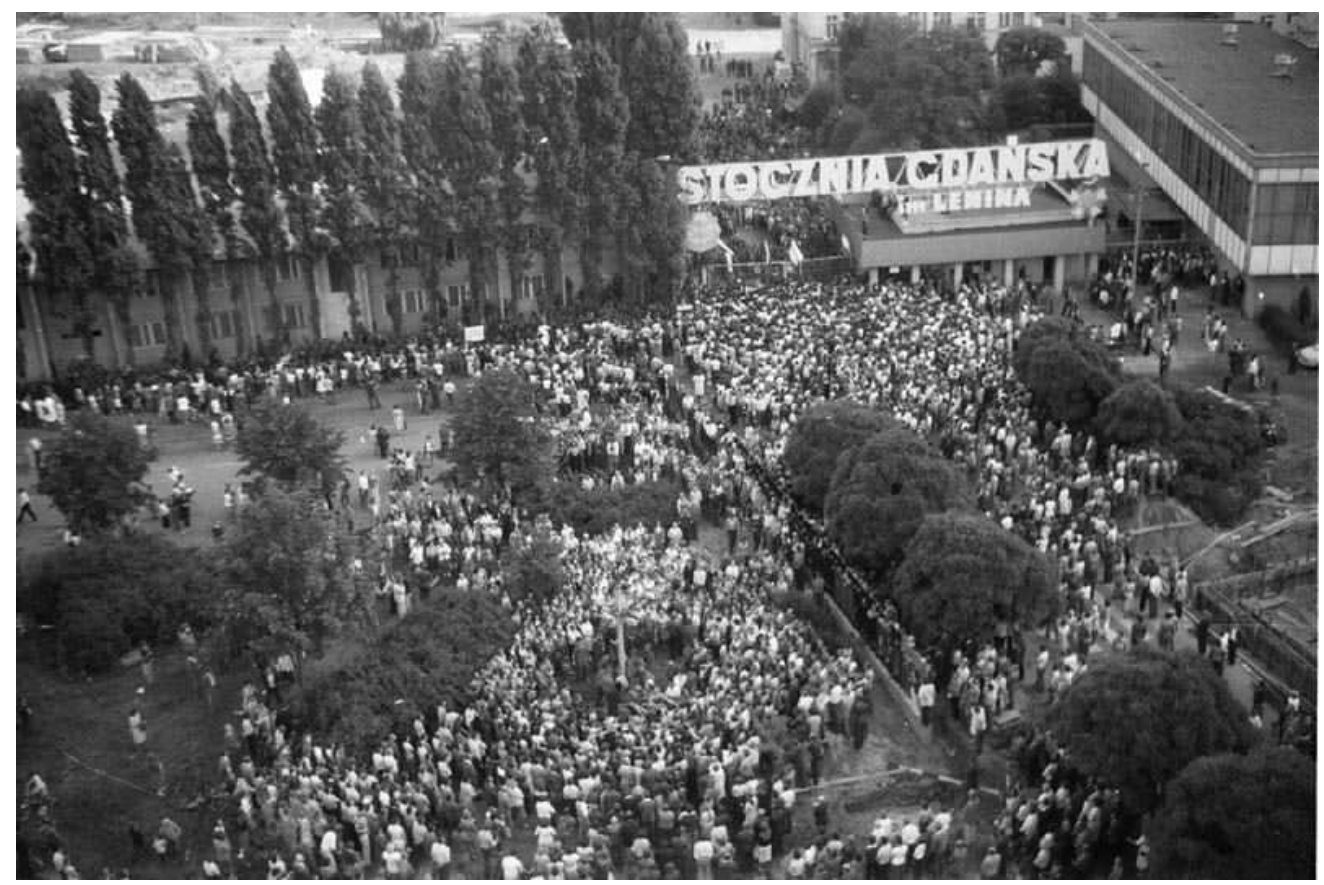

August 1980, large crowds in the front of the Gdansk Shipyard. The strikers are locked inside.

First, there was the transformation of the goals of the workers' struggle. The mere economic demands transformed into social and political issues. The striking workers demanded not only better salaries, but also freedom for political opposition and respect for human rights. While most of the 21 points of the Gdansk agreement dealt with labor matters such as wages, working conditions, or health insurance, its core was political. It contained

M. Moore (New York: Karz-Cohl, 1982); Gale Stokes, ed., From Stalinism to Pluralism: A Documentary History of Eastern Europe since 1945 (New York: Oxford University Press, 1991).

${ }^{9}$ For the best eyewitness account of a foreign journalist, see Timothy Garton Ash, The Polish Revolution: Solidarity (New York: Viking Penguin, 1991).

${ }^{10}$ On the August strikes and negotiations in the Gdansk Shipyard, see Neal Ascherson, The Polish August: The Self-Limiting Revolution (New York: Viking Press, 1981); A. Kemp-Welch, The Birth of Solidarity. The Gdansk Negotiations, 1980 (New York: St. Martins Press, 1983). 
provisions for the workers' right to form free trade unions and the right to strike; and it dealt with such issues as freeing political prisoners, the legal definition of censorship (i.e., the passing of a law to this effect), and trade unions' access to the mass media.

Second, there was institutionalization of the struggle. The worker's protests of 1956 and 1970, although they led to some political changes in Poland, including changes of government, could not have a long-term influence on political life because there was no institution which would defend the conquests won during the struggle. It was finally in August 1980 that there arose a popular recognition that to defend the gains of the protests, an institution was needed, namely, the Independent Self-Governing Trade Union "Solidarity."

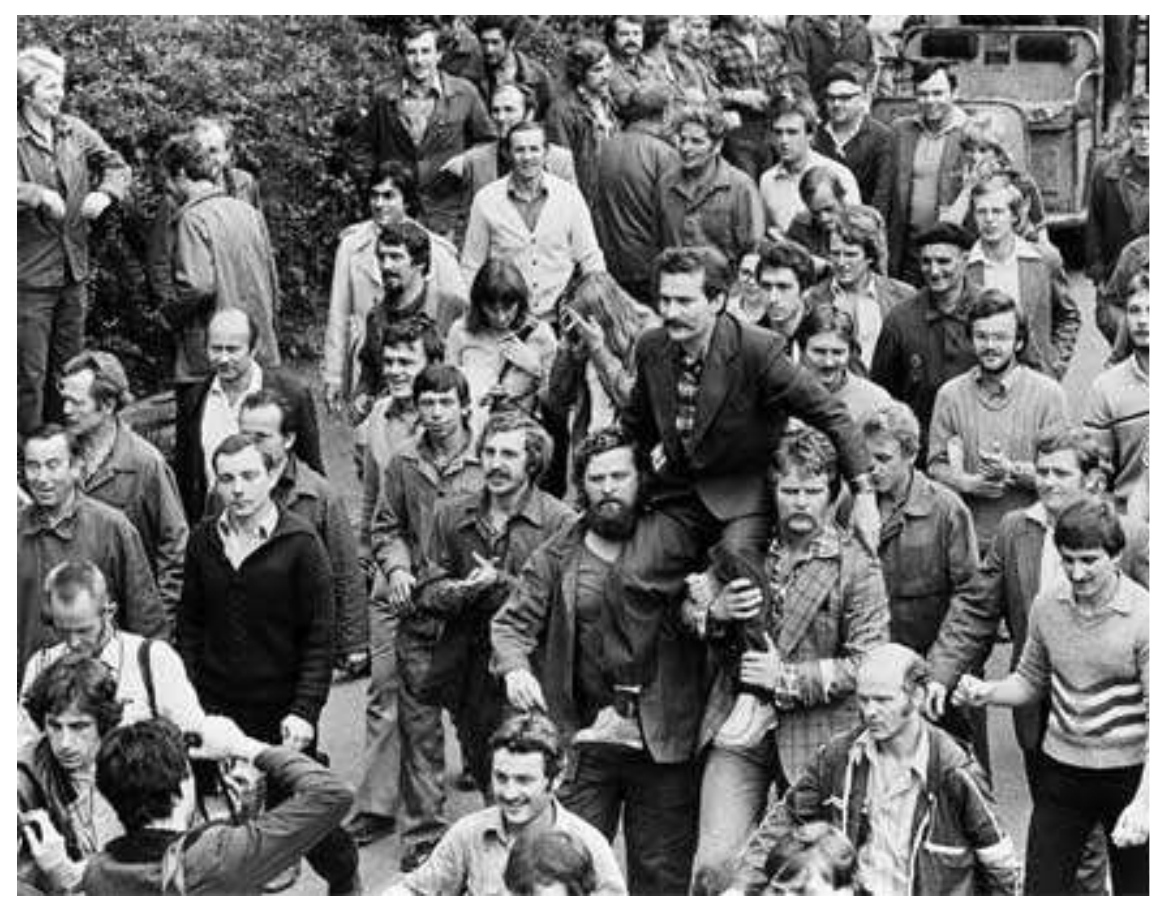

August 1980, the strikers leave the Shipyard after signing an agreement with the

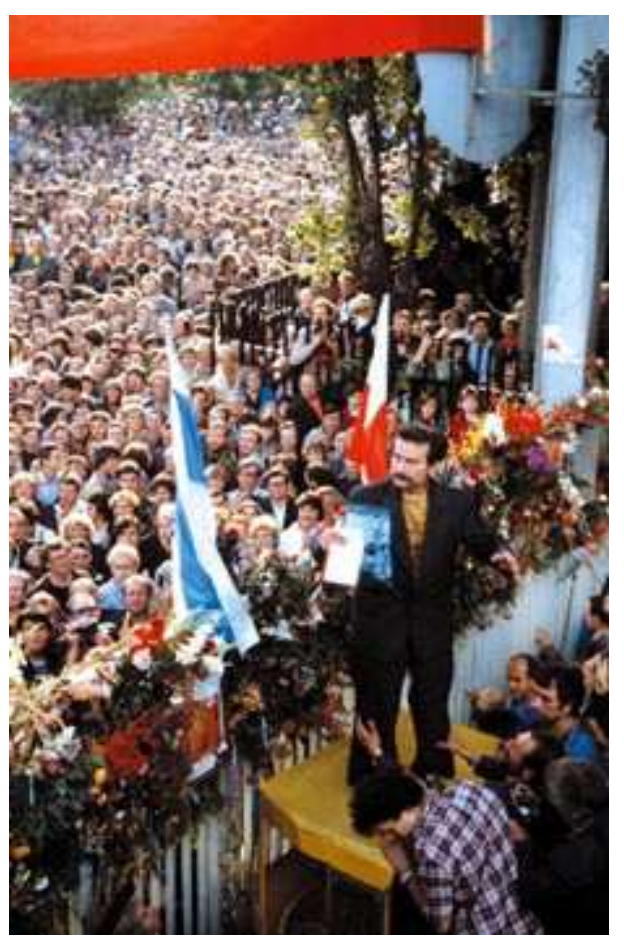

government. Lech Walesa, the leader of the strike, addresses the gathering.

Third, in August 1980, Polish society was for the first time truly united. Solidarity, the outcome of the August strikes, was an institution whose members were simple workmen, as well as members of the Academy of Sciences; activists of political opposition, as well as popular actresses and actors. The majority of Polish society became united by the program of economic, social, and political reforms of Solidarity.

Finally, there was a lack of ideology. Solidarity had not been an outcome of any particular social theory or philosophy. The intellectual disputes about it began after it was born. Solidarity arose rather as a result of popular recognition of certain human needs, such as food, truth and justice, a recognition that grew in Poland through the years following World 
War II. ${ }^{11}$ It should be stressed that the lack of ideology which would precede the birth of Solidarity was also a result of the complete bankruptcy of communist ideology in the eyes of the prevalent part of Polish society. With an ideology, there is always a dogma connected. People in Poland had a first hand experience of the harmful consequences of the dogmas of Marxism-Leninism.
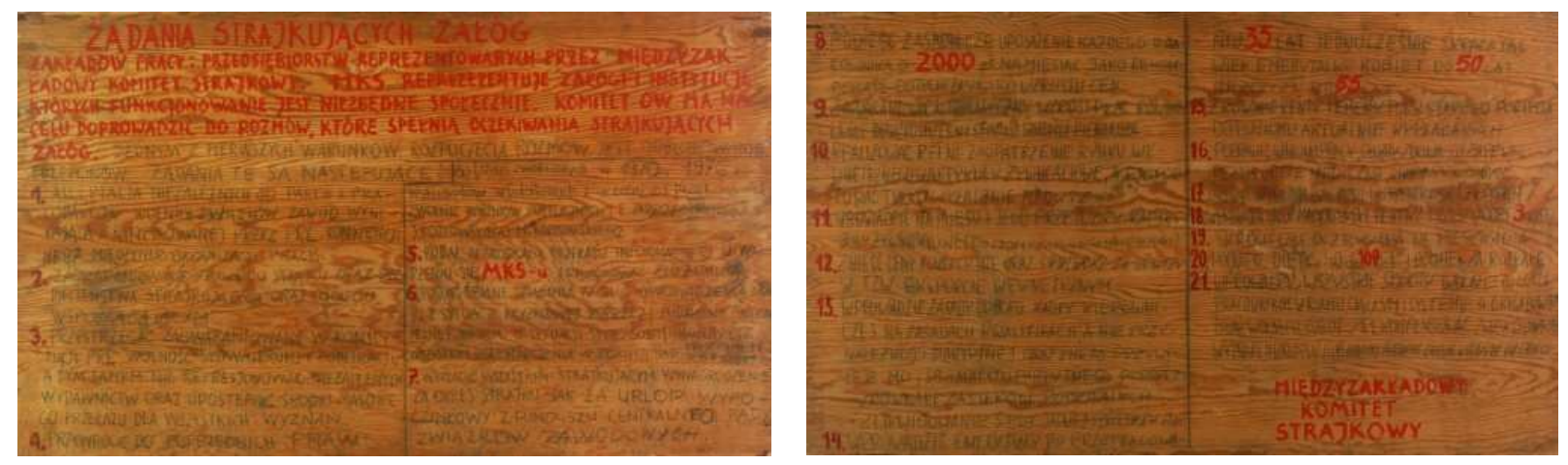

The wooden tables made at the Shipyard with the 21 points.

Why did the government give in and sign the 21 points? It was afraid of a massive uprising all over Poland, so it wanted to gain time. But from the moment Solidarity was born, the Polish party leaders began to draw up plans to crush it. ${ }^{12}$ Their monopoly threatened, the communist authorities were unable to come to terms with the independent trade union. Initially, Solidarity wanted to act within the limits of normal trade union activities. However, the external conditions imposed on it by the totalitarian system, in which there was no competing political parties, forced the union to exceed these limits by proposing to the government several reforms in education, law and economy, as well by supporting the independent organizations and institutions which, born along with Solidarity, were unable to defend themselves against party-state oppression.

\section{The Imposition of Violence}

\footnotetext{
${ }^{11}$ On the rise of Solidarity, see Lawrence Goodwyn, Breaking the Barrier: The Rise of Solidarity in Poland (New York: Oxford University Press, 1991); Jan Kubik, The Power of Symbols against the Symbols of Power: The Rise of Solidarity and the Fall of State Socialism in Poland (University Park, Pa: Pennsylvania State University Press, 1994); Roman Laba, The Roots of Solidarity: A Political Sociology of Poland's Working-Class Democratization (Princeton, N.J.: Princeton University Press, 1991).

12 On Solidarity's Challenge in 1980-1981, see Nicholas G. Andrews, Poland 1980-81: Solidarity versus the Party (Washington, D.C.: National Defense University Press, 1985); Peter Raina, Poland 1981. Towards Social Renewal, (Boston: G. Allen \& Unwin, 1985); Kevin Ruane, The Polish Challenge (London 1982); Jadwiga Staniszkis, Poland's Self-Limiting Revolution (Princeton, N.J.: Princeton University Press, 1984); Alain
} 
On 13 December 1981, the state attacked the society. Several thousand Solidarity activists were imprisoned, censorship of correspondence was implemented, and travel around the country limited. The imposition of martial law in Poland is still surrounded by a controversy. ${ }^{13}$ Was it to save the country from direct military intervention of the USSR? But was there a real danger of such intervention? In any case, imposed efficiently by Polish hands, martial law provided the best solution for the Soviets, considering the risk and possible harmful political consequences of a direct intervention. Its imposition was thus in the Soviet interest.

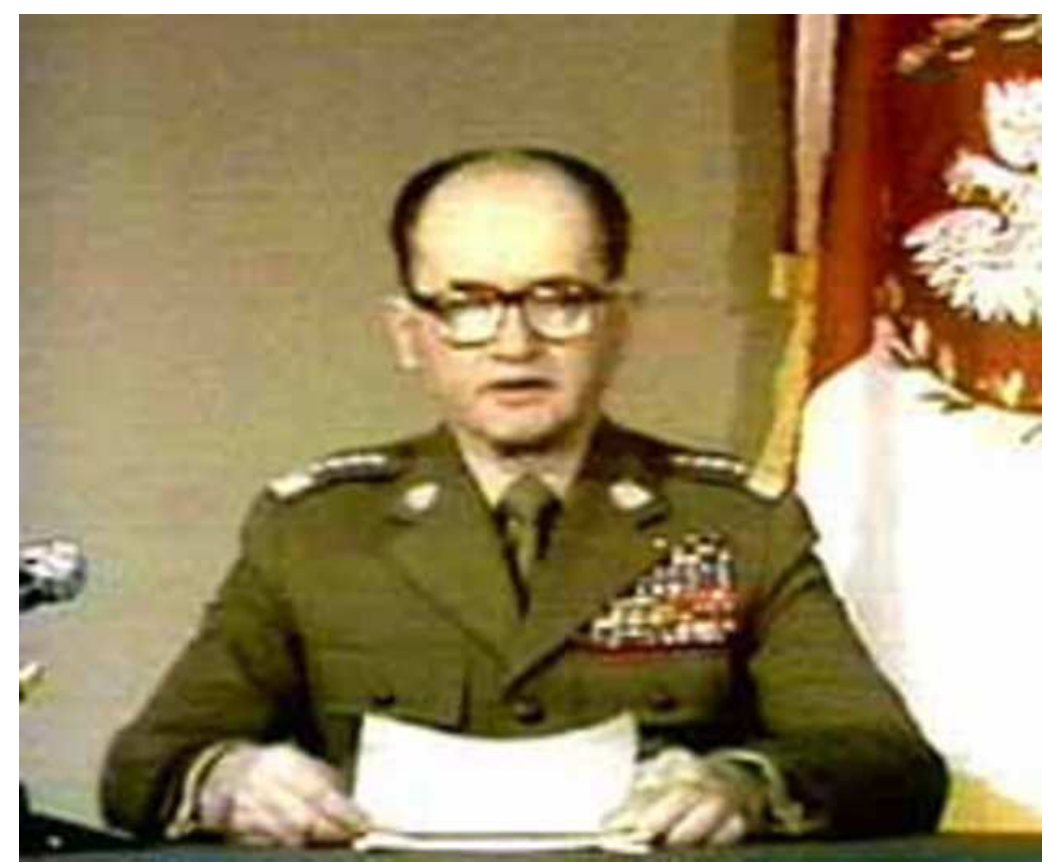

General Wojciech Jaruzelski announces the declaration of martial law on the state television.

With the approval of Moscow, by imposing martial law, the party-state apparatus decided on the tactic of terror because it represented an insignificant part of Polish society and was unable to otherwise impose its will on the majority. The ten million Solidarity members, along with members of Rural Solidarity and other independent organizations, such as the Independent Association of Students, together with their families, constituted the vast majority of the population of Poland. Less than one hundred thousand specially selected police and military forces were able to terrorize the movement of millions of unarmed,

Touraine, et. al., Solidarity: The Analysis of a Social Movement Poland 1980-81, trans. by David Denby (Cambridge: Cambridge University Press, 1983).

13 On martial law in Poland, see chs. 5-7 in Werner G. Hahn, Democracy in a Communist Party: Poland's Experience since 1980 (New York, Columbia University Press, 1987); Jan Mur, A Prisoner of Martial Law: Poland, 1981-1982, trans. by Lillian Vallee (San Diego : Harcourt Brace Jovanovich, 1984); Leopold Labedz, ed., Poland Under Jaruzelski, (New York: Scribner, 1984). 
peaceful people. The question now to be raised is: Why did Solidarity not respond with violence against violence directed towards it?
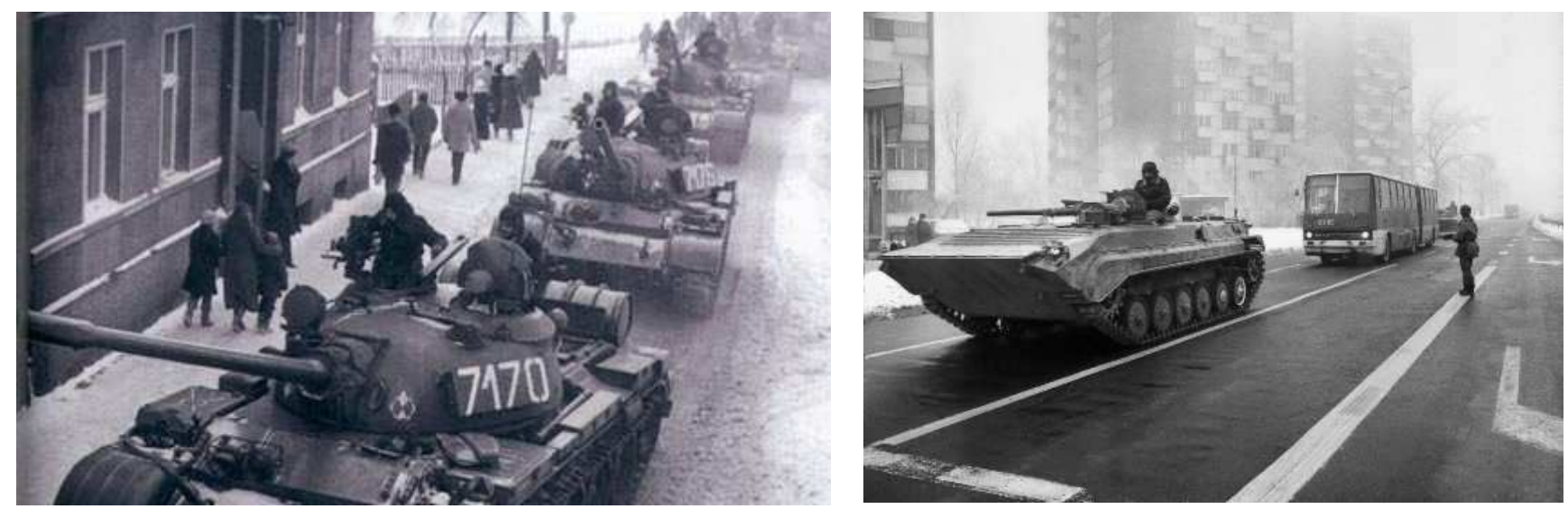

December 1981, tanks on the streets of Poland's cities.

The most obvious answer is that Solidarity was never, nor attempted to be, a military organization. Furthermore, in spite of all confrontation with the authorities during 1980-1981, there was always hope on the part of the majority of Solidarity's leaders that a dialogue with authorities, finding of a common ground and a common body of interests, was possible. In spite of all the economic, social and political demands which it made, Solidarity of 1980-1981 did not want to take over the power of the state, but rather to be a check on this power, so as to prevent it from being misused.

The belief in the possibility of dialogue with authorities made Solidarity completely unprepared to defend itself in case of a violent confrontation. The only form of defense was a total strike. And indeed, thousands of enterprises went on strike in order to protest the imposition of martial law. All these strikes were broken by force. The iron gates of Gdansk Shipyard were torn apart by tanks and workers returned to work. The only place where the workers defended themselves by force were two Silesian mines, "Wujek" and "Jastrzebie." At the coal mine "Wujek" the workers used fire extinguishers and metal tools against the police armed with weapons. Nine of them were tragically killed and the strike was broken.

The answer that Solidarity was not prepared for a violent resistance would, however, be all too simple. The popular image of Solidarity was at the time so high that of three million party members, at least one third joined Solidarity. These were mostly ordinary working people. Further, this high image went beyond the working people, reaching as far as the military and police forces. In 1981, a Solidarity cell was formed within the police. However, it was not officially recognized by the authorities. Consequently, one can suppose that if on the 
part of Solidarity leaders there was a call to defend oneself by force, there would be mass resistance, and at least some military and police forces would be prepared to support the position of Solidarity. Yet there was no such call. The striking workers were asked not to resist and to surrender to force.
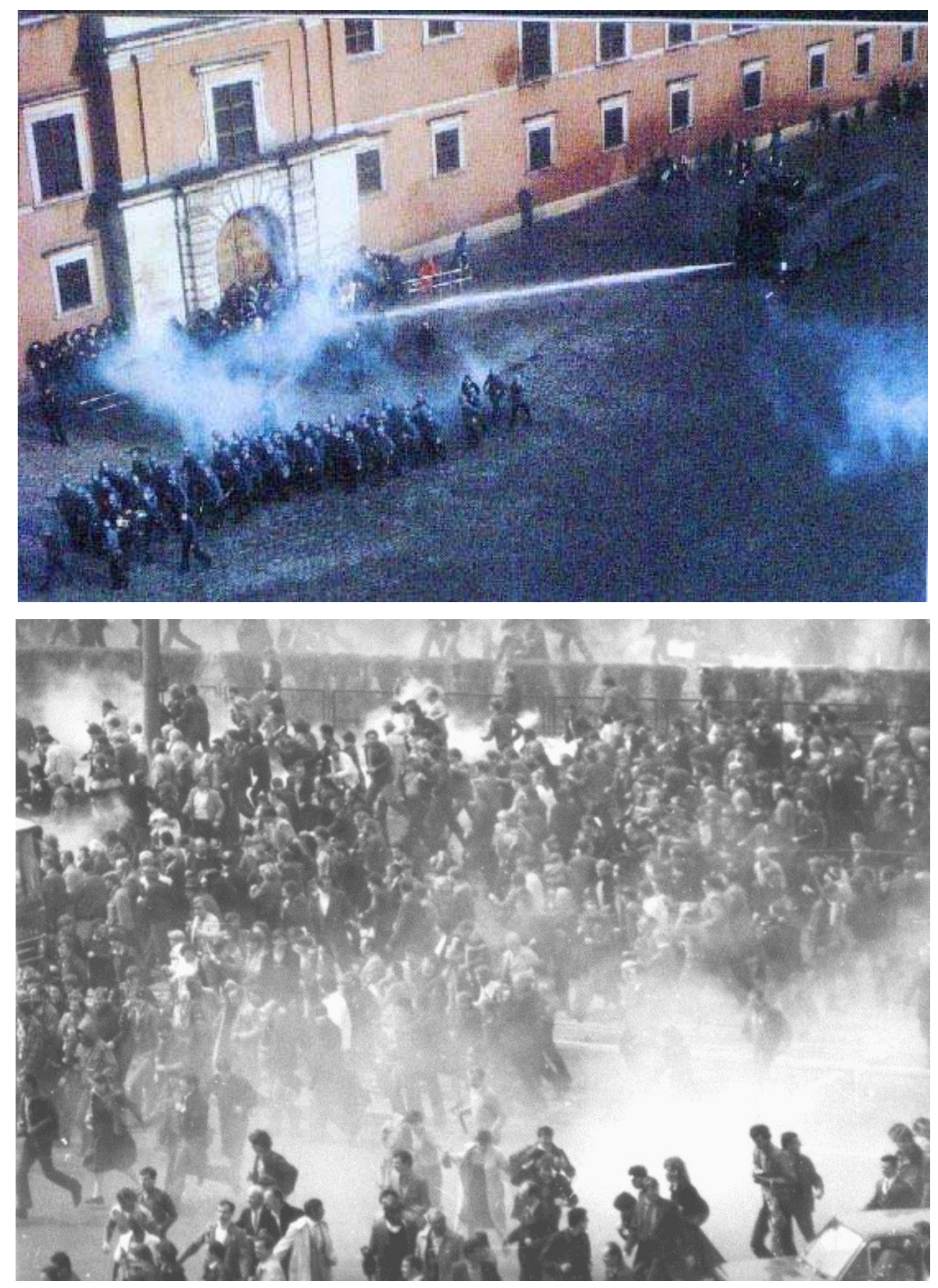

Warsaw 1982, despite of martial law protests in Poland continue. 
The forming of Solidarity in August 1980 was a spontaneous act on the part of the people who, in common, had learned from the mistakes of the past crises in Poland, of 1956, 1968, 1970 and 1976. However, by December 1981 Solidarity had become a well organized institution guided by a large body of its leaders and advisers, as well as a coordinated social movement. The peaceful response to violence was then a conscious act of Solidarity's leaders. Was this an ethical decision or a pragmatic choice?
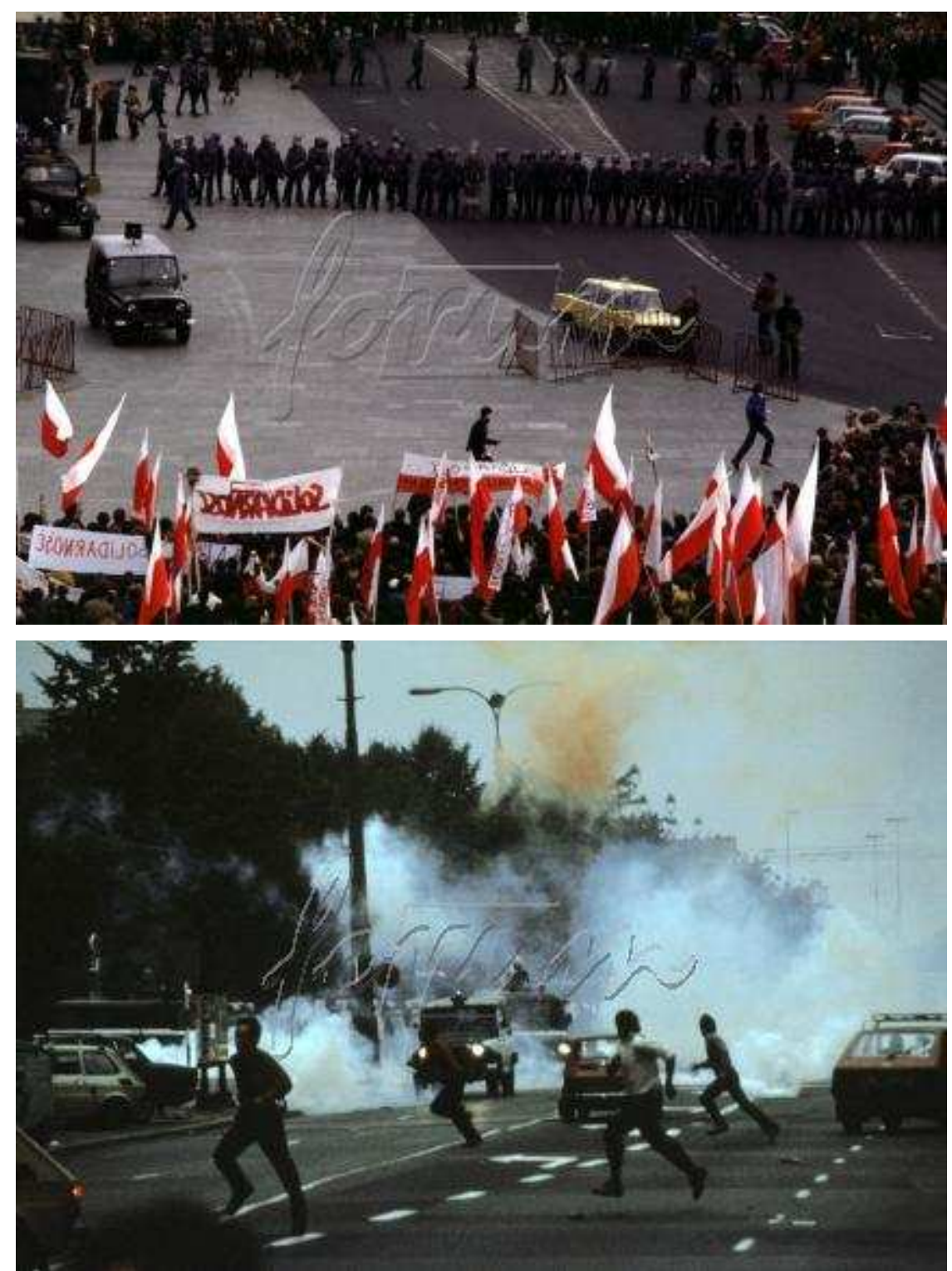

Warsaw, a nonviolent demonstration and a violent response.

In order to answer this question we need, for a moment, to look at Poland's history. The last two centuries were for this country indeed full of suffering. By the end of the eighteenth century Poland was divided between three powers of Russia, Prussia and Austria. 
The history of Poland in the nineteenth century is marked by desperate attempts to regain national independence, and particularly by the November 1830 and January 1863 insurrections against Russia, both ruthlessly suppressed. It was only because Polish refugees of the nineteenth century found suitable conditions outside Poland, especially in France, that Polish national consciousness and culture were cultivated independently, outside the annexing countries. In the twentieth century World War II had completely changed the picture of Poland, which, for the twenty-year period between the First and Second World Wars enjoyed again full independence and very prosperous development. Six million Polish citizens were killed during the war, including three million ethnic Poles. ${ }^{14}$ Cities, villages, and the country's infrastructure were to a large degree destroyed. Again, during World War II there were desperate attempts to liberate the country. Poland had an extensive and well organized underground. ${ }^{15}$ The Polish Army operating on both Western and Eastern fronts was fourth in terms of strength and number in the anti-German coalition. The courage and dedication of Polish people had contributed to the victory of the Allied Forces over Nazi Germany, but the pact signed in February 1945 in Yalta sealed the country' fate. ${ }^{16}$ Poland had fallen into the sway of communism. Consequently, the war was a painful lesson, especially the Warsaw uprising of 1944, after which the city was raised to the ground and thousands of innocent civilians killed. This is the price of violent resistance. The greatest tragedy is evident when, in spite of all dedication, suffering and blood, the political goals are not achieved. Then such a resistance remains an example of bravery and patriotism, but also a painful lesson for future generations.

Indubitably the painful lesson of Polish history teaches that one always should calculate whether or not violent military resistance can be successful. Such resistance is always connected with the possibility that it could be bloodily suppressed, and thus bring more harm than good. The consideration of Solidarity leaders that violent resistance to martial law, instead of improving the situation in Poland, might lead only to the death of the most dedicated and patriotic people was certainly sufficient for making the decision not to resist

\footnotetext{
${ }^{14}$ On crimes against Polish population, see Szymon Dater, et. al., War Crimes in Poland's Genocide 1939-1945 (Poznan: Wydawnictwo Poznanskie, 1962); Richard C. Lucas, The Forgotten Holocaust: The Poles under German Occupation, 1939-1944 (Lousville, K.Y., University Press of Kentucky, 1986).

${ }^{15}$ See Stefan Korbonski, The Polish Underground State: A Guide to the Underground 1939-1944, trans. by Marta Erdman, (New York: Columbia University Press, 1978).

16 See John L. Harper, Andrew Parlin, The Polish Question During World War II (Washington, D.C.: Foreign Policy Institute, 1990); Jan Karski, The Great Powers and Poland 1919-1945: from Versailles to Yalta (Lanham, M.D.: University Press of America, 1985).
} 
force and to surrender. By not resisting the force against which one cannot defend himself, one hopes to preserve one's life. Thus, he/she makes a pragmatic or tactical move. One does not renounce his/her ideas, but only suspends their practical implementation for a period of time.

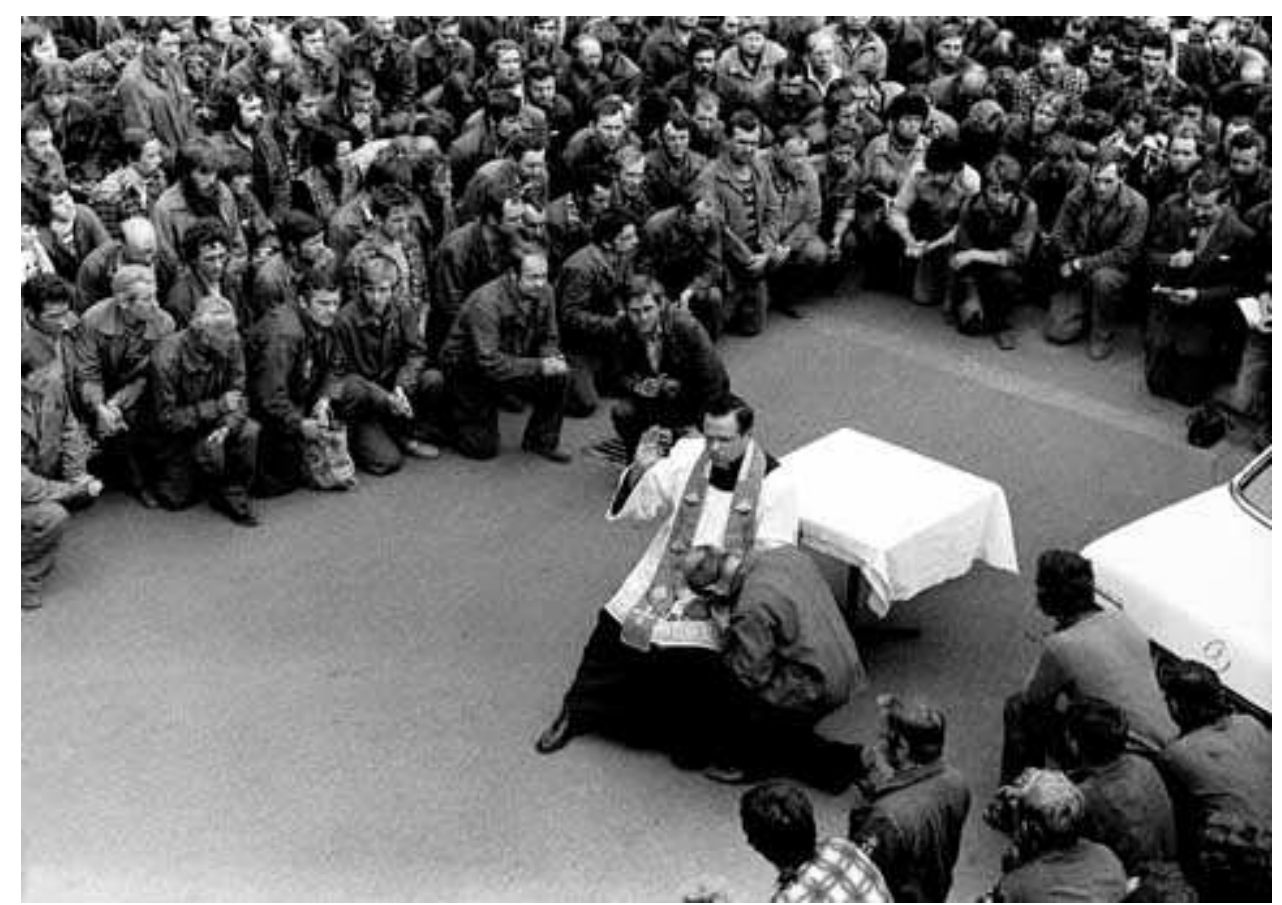

August 1980, a religious service for the strikers at the Gdansk Shipyard.

However, the nonviolent political struggle of Solidarity was not only guided by pragmatic considerations of how to achieve the goals more effectively, but also by ethical principles. Solidarity of the 1980s was a mass movement based in a society in which traditional Christian values were still very much alive - even among those people who did not regularly go to church. ${ }^{17}$ The transformation of the goals of the worker's struggle which occurred during the August strikes, from economic demands to social and political issues, had gone even further and can be rendered as a desire to replace lies with truth and to free oneself from hate. Therefore, there is a grave moral content that can be assigned to Solidarity on an equal basis with the economic, social and political reforms. Solidarity can rightly be called a movement of renewed morality because such traditional notions as truth, justice and freedom,

\footnotetext{
${ }^{17}$ On Solidarity's peaceful resistance in 1982-1988, see Grzegorz Ekiert, The State Against Society: Political Crises and Their Aftermath in East Central Europe, (Princeton, N.J.: Princeton University Press, 1996); Michael T. Kaufman, Mad Dreams, Saving Graces. Poland: A Nation in Conspiracy (New York: Random House, 1989); John Rensenbrink, Poland Challenges a Divided World, (Baton Rouge, Louisiana State University Press, 1988).
} 
ridiculed once in the Communist Manifesto and distorted in the practice of communism, had found in it again their original meanings.

\section{Movement Towards Freedom}

In the Informational Bulletin "Solidarnosc," 18 published in Gdansk on 19 January 1981, there was an article by Mariusz Wilk entitled "Freedom from Hate." In this article, he wrote:

There is a peculiar change, a phenomenon which has occurred simultaneously with the economic, social, political and cultural changes initiated in recent months by Solidarity. I shall call this change a movement towards freedom. By freedom, I hereby understand an act of releasing oneself from hate. This is for me the greatest conquest of August 1981.

And he writes further:

Totalitarianism poisons with hate both those who are its followers and those who resist it. One can neither conquer nor resist totalitarianism, one can only overcome it. Liberation from hate is also liberation from passivity to solidarity. This is again the greatest achievement of Polish society since World War II.

On 24 April 1986, Mariusz Wilk, then thirty-three years old, former editor of the Informational Bulletin of Solidarity, the co-author of the underground bestseller entitled Konspira, ${ }^{19}$ was arrested and charged with violating Act 132, i.e. cooperation with a foreign organization whose activities are harmful to the state. Evidence for this charge was a copy of a contract with an Italian publisher for publication of Konspira, found during a police search at his home. He was kept in a cell without much light, apparently to harm his sight. He was released during the September 1986 amnesty.

If one uses force against another, the latter has a right to defend himself. Yet, he/she may stand beyond the level of hate and retaliation. Thus, he/she consciously accepts the principles which have been handed down by the Christian tradition. These principles are still very much alive in Poland and this is a second answer as to why Solidarity was not a violent movement.

\footnotetext{
${ }^{18}$ In Polish Biuletyn Informacyjny “Solidarnosc.” Translations of the quotations below are my own.

${ }^{19}$ Maciej Lopinski, Marcin Moskit and Mariusz Wilk, Konspira. Solidarity Underground, trans. by Jane Cave, (Berkeley, California: University of California Press, 1990).
} 


\section{Conclusion: A Turning Point in our History}

Looking from today's perspective, the tactics and ethics of Solidarity, employed for the sake of political struggle in the 1980s, have proved to be the right ones. After new waves of strikes in 1988, the newly appointed government, taking advantage of the reformist trends introduced in the USSR by Mikhail Gorbachev, took steps to liberalize the economy and opened dialogue with political opposition. ${ }^{20}$ The so-called Round Table Talks, on the conditions of a peaceful reform of the political system, started in February 1989, lasted for two months and resulted in a constitutionally defined agreement to move toward democracy. Solidarity was restored as a legal organization. In June 1989 the first partially free elections were held. Solidarity's Citizens Committees gained 35 percent of the First Chamber seats (the other 65 percent was reserved for the communists (PZPR) and their coalition partners). Even so, the communists failed to produce the majority because their partners, the puppet peasant and democratic parties, switched sides and lined up with Solidarity. In the Senate, 99 out of 100 seats went to Solidarity. In September 1989 the first non-communist government in a Soviet satellite state was formed.
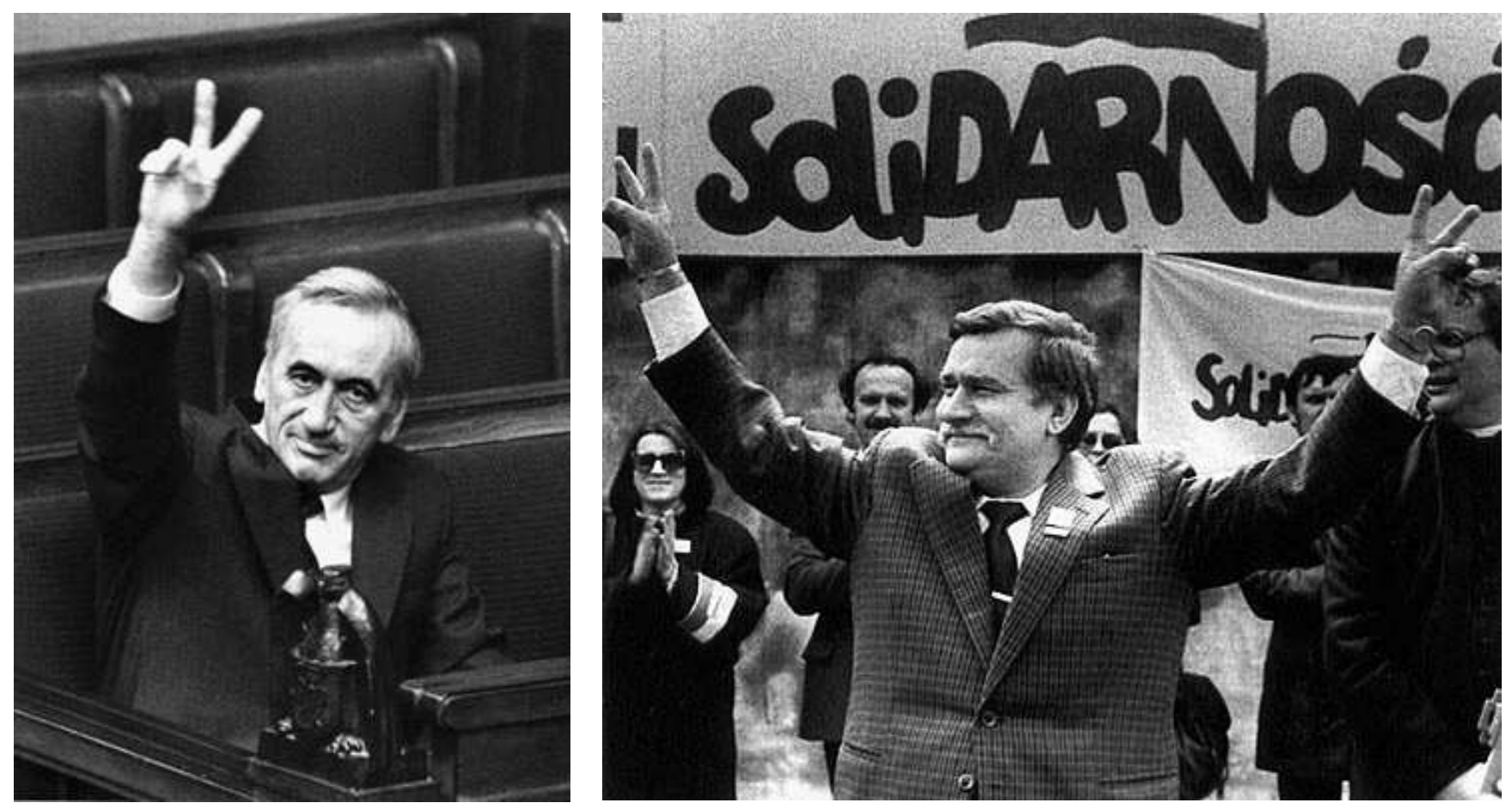

June 1989, Solidarity wins. With the help of Lech Walesa (right), the first non-communist government in the Soviet bloc comes into being with Tadeusz Mazowiecki (left) as Prime Minister.

\footnotetext{
${ }^{20}$ See Jadwiga Staniszkis, The Dynamics of the Breakthrough in Eastern Europe. The Polish Experience, trans. by Chester A. Kisiel (Berkeley, California: University of California Press, 1991).
} 
The sudden and unexpected collapse of communism in 1989 in Poland and in other countries of Central and Eastern Europe, often symbolized by the fall of the Berlin Wall, took even close observers of the region by complete surprise. The breakthrough made by Solidarity paved the way for some of the most significant events in the recent world history. It has led to the institution of democracy in several countries, the dissolution of the Soviet Union and the birth of new states, the reunification of Germany, the enlargement of NATO and the expansion of the EU. It has resulted in dramatic political, economic, and cultural changes that followed all over the world. In the aftermath, different interpretations of what happened were made, the most common being that communism could not compete economically with democracy, and as a result between 1989 and 1991 most of the former communist countries abandoned that system. ${ }^{21}$ But, as today's examples of North Korea, China, Cuba, and other countries can show, economics by itself could not crush such a powerful ideology as communism, which has a high degree of persistence and can adapt itself to the changing international environment. The turning point of history was the series of events that took place nine years earlier, in August 1980, when Solidarity was born at the Gdansk Shipyard. Without the birth of Solidarity, there would have been no fall of the Berlin Wall. The Gdansk Shipyard, in which massive strikes and other forms of peaceful resistance were initiated, became the place that inspired the rest of Poland with freedom, and Poland soon began to have a similar effect on other countries of Central and Eastern Europe. The birth of Solidarity was the crack in the structure of the Soviet Block that began the end of the totalitarian system

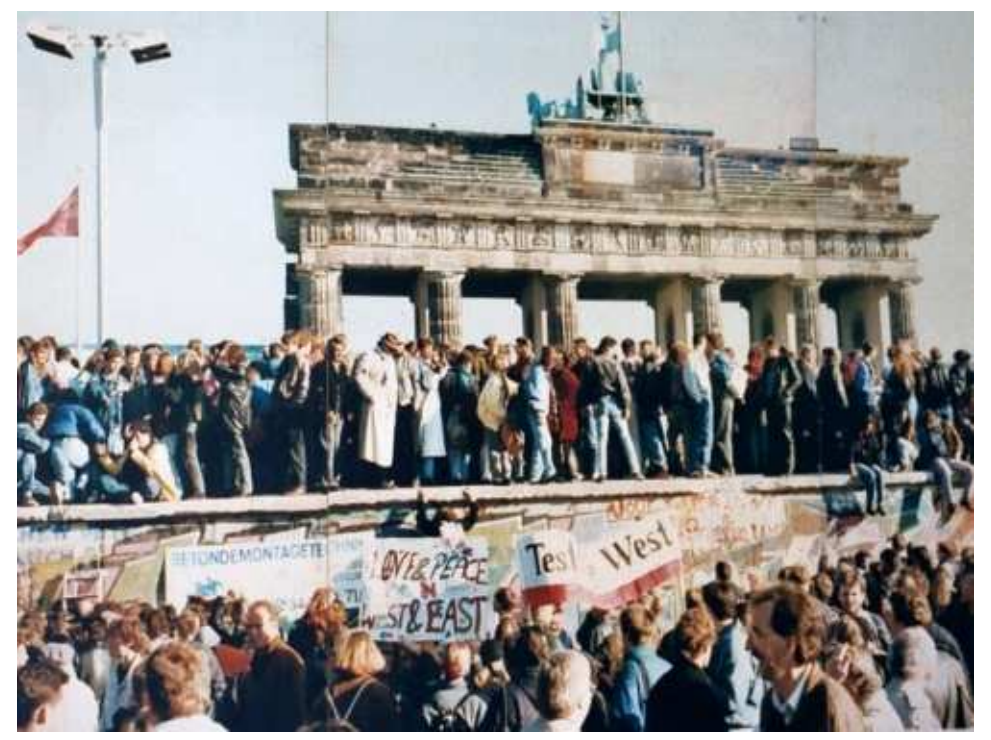

November 1989, the Fall of the Berlin Wall.

\footnotetext{
${ }^{21}$ Tom Lansford, Communism (New York, NY: Marshall Cavendish Benchmark, 2008), p.83.
} 


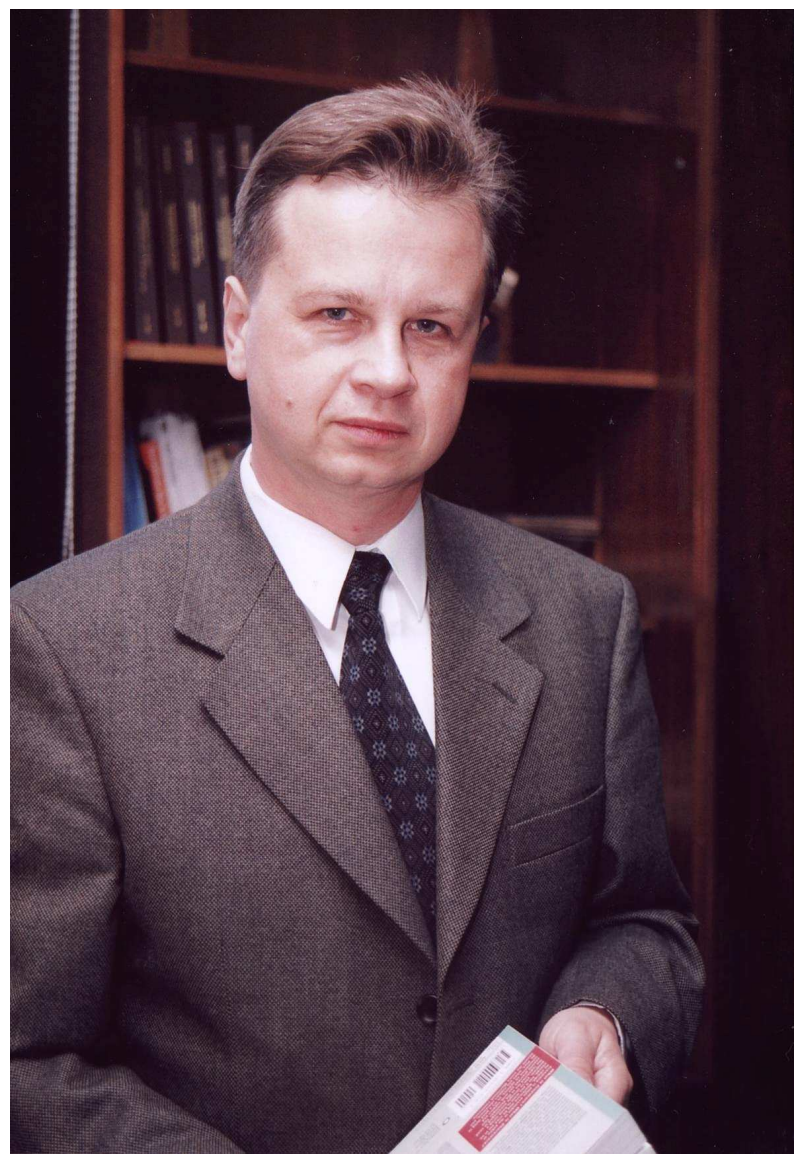

W. Julian Korab-Karpowicz is a associate professor of International Relations and Philosophy at the Anglo-American University of Prague. Raised in Poland, during 1980-1981 he was a student Solidarity leader. Forced into exile, he continued studies in Canada, the United States and the United Kingdom, and supported Solidarity from abroad. He has received a Ph. L. from the Catholic University of American and a D.Phil. from the University of Oxford. After his return to Poland in 1991, he was elected Deputy Mayor of Gdansk. He founded the Sopot School of Polish. He also served as a diplomat at the Embassy of Poland in Norway. He has published articles in a number of journals. He is the author of A History of Political Philosophy (New York: Global Scholarly Press, 2010).

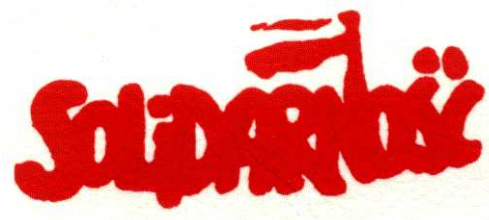

